\title{
Medieval Sources of the Modern Symbolic Meaning of the Sword
}

\author{
Daniil Lobach \\ Bauman Moscow State Technical University \\ 5/1, 2nd Baumanskaya St. \\ Moscow, Russia 105005 \\ E-mail: mailebox1984@mail.ru
}

\begin{abstract}
The paper analyzes one of the most often used modern symbols - the sword, dwells upon the main stages of the sacral and symbolic significance of the sword. Results of the research suggest that the roots of the modern symbolism of the sword date back to the Middle Ages. Much attention is given to the meaning of the sword in the context of medieval judicial practice. The author touches the issues of the important role of the sword as a marker of the certain social status in the structure of medieval society. The influence of religious teachings on the formation of key elements in the sacred meaning of the sword is determined by the main factor. The study also examines the main stages of the formation of the symbolic value of the sword.
\end{abstract}

Keywords-sword; Europe; Middle Ages; symbolism; sacred meaning

\section{INTRODUCTION}

To fully understand the historical process, it is necessary, among other things, to consider modern neoclassical models of historical knowledge. An important element of modern models of historical knowledge is the inseparability of the historical process and the prolonged existence of many elements of earlier historical stages into later and modern times [1].

The influence of elements of medieval culture on modern society is extremely big. One of the most common symbols is the sword in various forms. Since the XVII century the sword has lost its value as a weapon. Research papers devoted to the sword appeared in the XIX century as a result of the loss of relevant knowledge about this type of cold steel. Some cases when a sword was used in the form of cold weapons in the conflicts of the 20th century only confirm the loss of the value of the sword as an effective weapon. However, the symbolic value of the sword remains relevant in the 21 st century because the old elements of the mentality are characterized by social inertia and conservatism [2], and weapons and the sword in particular are some of the most archaic elements

In modern culture, we can see that science fiction writers simulating the image of the future, often use the sword as an integral attribute. A series of films like "Star Wars" can provide an example of this statement. Such kind of modern art as computer games also often uses the sword even in the setting of science fiction. One can pay attention to the use of the sword as an element of emblem design of various "power" departments of both post-Soviet and Western countries. The sword in the modern world directly affirms the justice and legitimacy of the use of force by its possessor.

Usually the ancient culture of Greece and Rome is the source of various modern phenomena. This statement is not true, however, if we concern the sword. For the period of antiquity, the perception of the sword is not typical, except as a practical tool. In the Middle Ages, the sword becomes not just a military tool, but a multifaceted symbol inherent in the culture and way of life of Europe. Symbolic aspects of weapons in the Middle Ages, and, in particular, the sword were described by such researchers as J. Flori [3], F. Cardini [4]. The issue of symbolism of the sword in the spiritual life and traditions of Kyivska Rus was considered in the works by I. Kirpichnikov [5]. However, the problem of symbolism of the sword in the spiritual, legal and other spheres of social life of Medieval Europe, in our view, is not thoroughly studied. The purpose of this paper is to analyze the symbolic value of the sword in life of medieval European society.

\section{THE ORIGINS OF MYTHOLOGIZATION OF THE SWORD IN THE MIDDLE AGES}

The symbolic meaning of an object is often determined by the attitude toward its creator or its possessor. The activity of the gunsmith, who could forge swords, was considered in the Early Middle Ages as an occupation close to witchcraft. The roots of the medieval European tradition, "... which made from the armorer, along with goldsmiths, a sacred creature ...", should be sought in the customs of the barbarian, Scandinavian and Germanic societies. In the "Poetic Edda" (a collection of ancient Icelandic songs about the gods and heroes recorded in the second half of the 13th century), and numerous sagas there are many references to powerful blacksmiths: Alberic, Mime, Rigene, Siegfried, who forged the matchless sword of Nothung, Wayland and others. For example, this is how the work of the divine Wayland the Smith is described in the "Vilkina saga": "The King said: "Good Sword" and he wanted to take it to himself. Wayland answered: "It is not good enough, it needs to get better, and I will not rest until I get it". Wayland returned to his forge, took the file, ground down the sword into small 
chips and mixed them with flour. Then he fed this mixture to domesticated birds, which he kept without food for three days. He melted the bird droppings in the furnace, got iron, cleared it of scale and again forged a sword of the size less than the first one. The sword was good to the hand. The first swords produced by Wayland were bigger than ordinary ones. Having found Wayland, the king praised the sword and assured that it was the sharpest and the best of all swords that he had ever seen. They went down to the river. Wayland took a piece of wool three inches thick and of the same length and threw it into the water. He calmly dipped the sword into the river, and the blade cut the wool as easily as it dissected the current... "[6].

The lack of scientific knowledge in metallurgy and physics led to the mythologizing of the technological process. The lack of scientific rationality [7], due to the formation of which the transition from the Middle Ages to the New Age occurred, led both philistines and metallurgists to the "magic" field. The making of the sword was surrounded with an aura of mystery, due to which, in medieval legends and stories, it was often endowed with supernatural properties. Let us recall the sword of the legendary King of Ireland Nuada Silver Hand, which was impossible to fight off; the sword of the Scandinavian god of summer and fertility Freyr, which could fight by itself; Excalibur, which was the magic sword of King Arthur, it could not be blunted, and its scabbard healed wounds; the sword Kladenets (steel-sword) from the island of Buyan from Russian folklore. Christianity as it spread in Europe in the 4th and 10th centuries, faced with pagan traditions of sanctification of weapons, and, wishing to attract not only the lower but also the higher classes to the church, gradually changed its traditions and rituals to give some features of a Christian sacred symbol to weapons, and the sword. There is a new Christian paradigm, according to which the sword becomes a symbol of the Christian faith.

Along with the Gospel, a "sacred weapon" becomes a full participant in the Christian rite of taking the oath. Suac oath was equal to the gospel-oath. According to F. Cardini, the question of the equivalence of weapons and the Gospel was the central issue "... of the entire Roman-Christian" methodology "of taming and subordinating Christianity to German paganism": "The warrior with arms in his hands felt much more confident. He knew that Christianity sought to perfect the ancient laws. Even calling on for the laying down arms, Christianity, however, did not consider arms to be something unworthy of a Christian. Therefore, it was possible to become a Christian without refusing the covenants of the ancestors. Such motivation contributed to attracting the Germans to the side of Christianity. In doing so, Christianity, however, made a minor concession.

Indeed, it would not be easy to justify the renunciation of military violence with the help of the Old Testament. Paganism received additional justification due to the Old Testament. Paul himself, speaking of the "spiritual sword", and the Apocalypse, which combined the symbolism of the book and the sword, served as the justification of an oath at the level of the symbolic language, the oath being "either the gospel-oath or made on arms." Between the idea that the
Gospel is a weapon and that the sacred weapon is equivalent to the Gospel, there is conceptually a huge distance. However, agreeing with F. Cardini we can state that at a symbolic level, there is one step between them. The symbolic aspect of the sword is also related to the medieval theory of the two swords formulated by Pope Boniface VIII (1294-1303). According to the theory of the two swords, "... Christ gives the spiritual (church) Lord two swords as symbols of spiritual and secular power. And already the spiritual Lord, in turn, hands one sword to the secular sovereign and therefore has primacy over him "[8]. Therefore, the sword was one of the mandatory royal regalia of Western European monarchs.

In the medieval coronation formulas used in the AngloSaxon, German and French coronation ceremonies, the transfer of the sword symbolized the power that the church solemnly handed over to the kings to protect those who needed it. The sword of the king was to protect the state and the church from both external danger - attacks by enemies of Christianity, and to help maintain inner peace - to do justice and royal justice, following the guiding principles of the church. The emperor Carolus Magnus (747-814), known by descriptions for his modesty, always wore a sword not as an ornament, but as a symbol of power. On the funeral catafalque of the Holy Roman Emperor Frederick III (1415 1493), among other regalia of royal power - next to the crown, scepter and power - there was also the sword of the late monarch. The medieval lawyer Henry de Bracton (1268), author of the treatise "On the Laws and Customs of England", wrote that "... the sword means the protection of the state and the country", and also pointed out that kings, promoting vassals in noble title "... give these people high dignity, power and name, when they encircle them with a sword, that is, a belt on which the sword hangs."

In Kyivska Rus the sword was also the most important military and state symbol. First of all, the sword embodied the power of the prince. The grand prince of Kiev Roman the Great (1150 - 1205) objected to the Pope's envoy Bernard de Clairvaux, who promised him the royal crown and support with the Pope's sword, as follows: "I have a sword by hand before the resolution (dispute). Then both sides must solemnly promise a duel (arrange it). When they are ready for the battle, they must come to the middle of this land and must touch it with the same swords they must fight with, and call the creator to witness, that to whom he will give the victory, on his side the justice (right) is, and then they must fight. The one who wins must own what they had a dispute about, and those others who tried to challenge his property must pay 12 solidities" [9]. In Kyivska Rus a "sword-bearer " is the rank of the judicial princely administration received its name from a sword that punishes untruth. The echoes of resolving disputes with the sword remained in Europe for a long time. In the privilege granted in $1174-1178$ to the Prague germans by the Czech duke of Bohemia Soběslav II (1126 - 1178), a way of proving innocence in theft, was the oath made in a circle outlined on the ground by a sword. In the "Immunity Privilegium for the Estate of Knight of Clemence of the Rush", signed by the Polish duke Bolesław $\mathrm{V}$ the Chaste (1226-1279) in 1252, a sword duel was 
categorized as the generally accepted means of judicial investigation, and in one of the earliest legal monuments of the feudal Czech Republic, The Rosenberg Book, compiled in the second half of the 14th century, it was appointed as a measure of restraint and the possibility of protection for the offender at the same time.

By the time of the Crusades the sword is unequivocally affirmed as a sacred weapon, probably due to a constructive similarity with the cross. This value of the sword will be great not only in the first crusade, but also in the crusades against the Slavs [10]. In France, judicial fights remained a way to administer justice until the fifteenth century, despite the attempts by state authorities to reduce their numbers to a minimum. They were allowed to resort only in cases where there was no evidence, and one had to rely only on "God's judgment" [11]. Later, the sword becomes an integral attribute of the knightly estate, nobility and noble descent in general. According to the "Sachsenspiegel" ("Saxon Mirror"), the oldest legal collection of Germany, drawn up in 12211225 , the swordsman who came to trial to his master had to relinquish all the signs of his noble estate, namely: "... a sword, and a knife, and spurs, remove gloves and all iron." "Polish Truth" or "Elblag Book", dating back to the 13th century, determined that the commoner who summoned the knight to the court of God had to fight him with the weapons of the nobility - the sword: "... but if the peasant called the knight, they had to fight with swords".

The sword is a weapon of the noble, therefore, in case the servant, defending his master, with a sword in his hands, inflicted wounds on a representative of a higher class than he himself belonged to, he did not bear any responsibility for his actions. His master was responsible for them [12]. The sword, and the royal sword in particular, acted as the supreme symbol of justice. For example, in the code of laws of medieval Sweden, the so-called "Landsläge" of King Magnus II of Eriksson (1316-1344) signed in 1347, the king's sword attributed the highest punitive function: "[If] the master or a watchman kills any of those who commit this (theft - author's note), then let them lie unrevenged, as if [they died] from the King's sword " [13]. Medieval legal monuments consider a sword, literally, as an instrument of justice. It is given great importance in the resolution of conflicts, in fact it replaces the institution of witnesses, lawyers and prosecutors.

The range of problems solved by means of the sword in the early Middle Ages was quite wide. One of the oldest "barbarous truths" - "Allaman truth" ("Lex Alamannorum"), which is a record of the customary law of the West Germanic tribe of the Alemannians of the late 6th - 8th centuries, assigns the solution of a number of disputed situations to the conduct of the sword. Firstly, by means of a sword duel, one's own dignity and honor could be defended: "If any free person ascribes to another freeman any crime that causes death and charges him with it in front of the king or the duke, and then the matter will not be confirmed, except by his own words, it is allowed to the one to whom the crime is imputed, with a drawn sword against the other to be justified".
Secondly, the disputed questions of inheritance were solved by the sword, in particular, according to the women's line: "If a close relative of the dead husband wishes to challenge the dowry of this woman, she must prove (by means of an oath with 5 named compurgator s or by a duel with a drawn sword. If she can acquire this property (win) by means of an oath or by means of a duel, then after the woman's death this property never returns (to her husband), but it must be possessed forever by the next husband or his children "[14].

Thirdly, by means of the sword, an important issue was solved, such as changing the boundaries of land plots and belonging of disputed territories: "If there is a dispute between two clans about the boundaries of their land and one says:" This is our border", the other will go to another place and say : "This is our border," there must be a commoner and he must put a sign where they want to establish the border. After the sign is placed, they must come in the middle and, in the presence of the count, take a certain amount of land and stick branches from the trees into it. Both clans, arguing among themselves, should put this land in the hands of the count. He must wrap it in cloth, put a seal and (pass it on) to the faithful person. "We decide, if it happens that any of those belonging to any estate quarrel, and the servant, helping his master, draws a sword or saber and wounds someone, then for this he should not be punished either by the injured, or by his friends, and only his master, if he is guilty, must be summoned (to appear before court) and be responsible (for the wound) "[15]. In the Portuguese "Pragmatics" of 1340 (the law designed to regulate the clothing and nutrition of people of different social status) the right to wear expensive and richly decorated swords was reserved only for members of the upper class.

\section{THE MEANING OF THE SWORD AS A SACRAL ATTRIBUTE OF DIFFERENT CLASSES}

The idea of the role of the sword in the life of a knight is also given by medieval epic poems, tales of chivalry. The main character of the "Song of Roland", dying, says goodbye not to his beloved or his relatives, but to his sword. Thus, he means that for the knight the whole world he was leaving, was focused on the sword, thanks to which it was possible to deserve the title, to protect his life and honor, to get rich. Here the sword is not just an instrument - it is both a true friend, and a defender, and, often, the last hope:

"Rollant ferit el perrun de sardonie.

Cruist li acers, ne briset ne n'esgrunie.

Quant il co vit que n'en pout mie freindre,

A sei meisme la cumencet a pleindre:

"E! Durendal, cum es bele, e clere, e blanche!

Cuntre soleill si luises e reflambes!

Carles esteit es vals de Moriane,

Quant Deus del cel li mandat par sun a[n]gle,

Qu'il te dunast a un cunte cataignie: 
Dunc la me ceinst li gentilz reis, li magnes.

Jo l'en cunquis Namon e Bretaigne,

Si l'en cunquis e Peitou e le Maine;

Jo l'en cunquis Normendie la franche,

Si l'en cunquis Provence e Equitaigne

E Lumbardie e trestute (r)Romaine;

Jo l'en cunquis Baiver e tute Flandres,

E Burguigne e trestute Puillanie,

Costentinnoble, dunt il out la fiance,

E en Saisonie fait il co, qu'il demandet;

Jo l'en cunquis e Escoce e Vales Islonde,

E Engletere, que il teneit sa cambre;

Cunquis l'en ai pais e teres tantes,

Que Carles tient, ki ad la barbe blanche.

Pur ceste espee ai dulor e pesance:

Mielz voeill murir qu'entre paiens remaigne.

Deus! Perre, n'en laise(i)t hunir France!" In the period of the High and Late Middle Ages, due to the improvement in the technology of manufacturing metal strips, the production of swords cranks out: this leads to a fairly wide spreading of swords outside the aristocratic circles, but on the other hand, it negatively affects the quality of these blades. So, swords become available to peasants and townspeople. Evidence is given, for example, by the text of the "Peace for the Rhine Franconia", referring to the reign of Holy Roman Emperor Frederick I Barbarossa (1123 - 1190): "The peace-breaker summoned by the judge to the court must come only with 30 men, no more than twenty-nine, so that he himself was the thirtieth; they all do not carry other weapons, except the sword ... Peasants and people of their class, going out to the outskirts, should not carry other weapons, except the sword" [16].

The prevalence of swords as a weapon among free people is confirmed by an extract from the document regulating the exploitation of silver and copper mines in Lyons and Beaujolais dating from 1475: "... none of the named masters, workers, laborers and servants should dare bring swords, daggers, darts and other weapons of attack, except for small knives for cutting bread and meat, to the mine, foundry, smithy, the houses and other premises, under fear of confiscation of the named weapon and [fine] in 10 Turks for each time, if they are found. " Evidence of the increasing role of the sword as an indispensable marker of the stronger sex is also the definition of male inheritance as "inheritance by the sword", and male relatives as "relatives by the sword" [17].

\section{CONCLUSION}

Despite the fact that in the Middle Ages the sword took the place of auxiliary weapons in a complex of weapons and armour, in accordance with its functional role, it received the status of a noble weapon, which demonstrates the personal courage and mastery of the owner in a fight, unlike longrange weapons. The biographer of the French King Saint Louis (1214-1270) Jean de Joinville (1223 - 1317) describes the then ideal battle as follows: "Believe that it was a remarkable battle with a weapon in hand, for there they did not shoot an archer or crossbow, but fought hand-to-hand, with batons or swords. " Since the beginning of the XIX century, cold steel has been losing its relevance. After the introduction of Maximgun in 80s of the XIX century and the appearance of self-loading rifles and pyrocoloid gunpowder, the cold weapon is finally turned into an auxiliary [18]. Thus, during the Middle Ages the sword is of enormous importance as a complex multifaceted symbol reflecting the position of the owner as a free man, the weapon of a righteous judgment, and also becomes one of the important symbols of religion [19]. This symbolic meaning of the sword is reflected in modern culture.

\section{REFERENCES}

[1] Komissarov I; Nekhamkin V. The Models of Historical Cognition: Current Status and Prospects of Development // Istoriya-Elektronnyi nauchno-obrazovatelnyu zhurnal. 2017. Vol. 8. Issue 2. DOI: 10.18254/S0001779-5-1

[2] Gubanov N.I., Gubanov N.N. The role of mentality in the development of society: sociocultural hypothesis // Vestnik slavianskikh kultur-bulletin of slavic cultures-scientific and informational journal. 2017. Vol. 43. № 1. P. 38-51.

[3] Flory J. L'Idéologie du glaive. Préhistoire de la chevalerie. Droz ; Genève, 1983. [In Russ.: Flory J. L'Idéologie du glaive. Préhistoire de la chevalerie. St. Petersburg, Evrazia Publ., 1999].

[4] Cardini F. The origins of medieval chivalry: [trans. from Italian / entry. art. V.I. Ukolova, gen. ed. V.I. Ukolova and L.A. Kotelnikova] / F. Cardini. Moscow, Progress Publ., 1987.

[5] Kirpichnikov A. N. Old Russian weapons: in 3 vol / A. N. Kirpichnikov. ML: Nauka Publ., 1966 - 1971. - Vol. 1: Swords and sabers of the 9th-13th centuries. - 1966.

[6] Jacques Le Goff. La Civilisation de l'occident medieval. Arthaud Paris 1977. [In Russ. Jacques Le Goff. La Civilisation de l'occident medieval. Moscow Progress-Academy Publ., 1992].

[7] Lebedev S.A. The Structure of Scientific Rationality // Voprosy filosofii. 2017. № 5. P. 66-79.

[8] Zotova L.V. Political Values of the Middle Ages: the Relationship of the Celestial and Earthly Fatherland by Augustine and Aquinas / L.V. Zotova // RUDN Journal of Political Science, no. 1 (5). - 2004. - p. 79 - 88. p. 84

[9] Alaman truth // Danilova G.M. Alaman and Bavarian society of the 8th and early 9th centuries / G.M. Danilov. Petrozavodsk: Karelia, 1969. - P. 162 - 189. p. 185

[10] Nesterenko A. N. Teutonic Order in the war 1240-1242 period // Voprosy istorii . 2014. № 8. P. 146-152.

[11] Defourneaux Marcelin. La vie quotidienne au temps de Jeanne d 'Arc / [trans. N. F. Vasilkova] / Defourneaux Marcelin. - St. Petersburg. : Publishing group "Eurasia", 2002.

[12] Kirpichnikov A. N. Old Russian weapons: in 3 vols / A. N. Kirpichnikov. - M. - L.: Nauka, 1966 - 1971. - Vol. 1.: Swords and sabers of the IX - XIII centuries. - 1966.

[13] Landslag King Magnus of Eriksson // Srednie Veka. Studies on Medieval and Early Modern History. - 1964. - No. 26. - P. 186 - 198.

[14] Alaman truth // Danilova G.M. Alaman and Bavarian society of the 8th and early 9th centuries / G.M. Danilov. Petrozavodsk: Karelia, 1969. - P. 162 - 189. p. 185. 
[15] Complete code of articles of Casimir III the Great (XIV - XV centuries) // History of Poland. - M.: Eurolinz, 2002. - P. 292-306.

[16] Frederick Barbarossa. The peace for Rhine Franconia 1179 / Friedrich I Barbarossa // Anthology of monuments of the feudal state and law of the countries of Europe / ed. V.M. Koretsky. - M., 1961.

[17] Charles I. The Lawyer "Majestas Carolina" (1355) Charles I. // Reader of the monuments of the feudal state and law of the countries of Europe / ed. V.M. Koretsky. - M., 1961.

[18] Lobach DV Evolution of handguns in the XVII - XIX centuries. // Humanities Bulletin of BMSTU. 2017. No. 9 (59). C. 1.

[19] Nesterenko A.N. Bishop Albert // Voprosy istorii. 2015. № 3. P. 5068. 